\title{
The teachers' extent of utilizing teaching methods for teaching basic technology
}

\author{
Omotayo Olabo Obielodan, Amos Ochayi Onojah*, Adenike Aderogba Onojah, Odunayo \\ Sunday Alabi, Emmanuel Adebayo Alimi \\ University of Ilorin, Nigeria
}

\begin{abstract}
The teaching method which teachers adopt for instruction could aggravate students' performance if successfully employed. However, its use may not be optimum as expected. This study investigated the extent of utilization of teaching methods used for teaching basic technology and the influence of gender on teachers' extent of utilizing teaching methods to teach basic technology. The study adopted a descriptive research design. One hundred twenty-two basic technology teachers in Nigeria were purposively sampled. The findings of this study were that question and answer, discussion, inquiry, and discovery, field trip, and project and presentation teaching methods are always employed by basic technology teachers in teaching while role-playing, game, and simulation teaching method are moderately utilized for teaching. Also, there was a significant difference between male and female teachers' extent of utilizing teaching methods to teach basic technology in favor of the male basic technology teachers. The study concluded that appropriate use of teachers' desired teaching methods could influence instructional delivery. It was thus recommended that educational institutions should organize conferences, seminars, training, and workshops for basic technology teachers on the use of effective teaching methods.
\end{abstract}

Keywords: Teacher, teaching method, gender, teaching, basic technology

\section{Luasan metode pengajaran yang digunakan guru untuk mengajar teknologi dasar}

\begin{abstract}
Abstrak: Metode pengajaran yang diadopsi guru untuk pengajaran dapat memperburuk kinerja siswa jika berhasil digunakan. Namun, penggunaannya mungkin tidak optimal seperti yang diharapkan. Penelitian ini menyelidiki sejauh mana pemanfaatan metode pengajaran yang digunakan untuk mengajar teknologi dasar dan pengaruh gender pada sejauh mana guru memanfaatkan metode pengajaran untuk mengajar teknologi dasar. Penelitian ini mengadopsi desain penelitian deskriptif. 122 guru teknologi dasar di Nigeria dijadikan sampel secara purposive. Temuan penelitian ini adalah metode pengajaran tanya jawab, diskusi, inkuiri, dan penemuan, kunjungan lapangan, dan proyek dan presentasi selalu digunakan oleh guru teknologi dasar dalam mengajar sementara metode pengajaran bermain peran, permainan, dan simulasi cukup digunakan. untuk mengajar. Juga, ada perbedaan yang signifikan antara guru laki-laki dan perempuan dalam menggunakan metode pengajaran untuk mengajar teknologi dasar yang mendukung guru teknologi dasar laki-laki. Studi ini menyimpulkan bahwa penggunaan yang tepat dari metode pengajaran yang diinginkan guru dapat mempengaruhi penyampaian instruksional. Oleh karena itu direkomendasikan bahwa lembaga pendidikan harus menyelenggarakan konferensi, seminar, pelatihan, dan lokakarya untuk guru teknologi dasar tentang penggunaan metode pengajaran yang efektif.
\end{abstract}

Kata Kunci: Guru, metode pengajaran, jenis kelamin, pengajaran, teknologi dasar

Received: $20-07-2021$ Accepted: 04-10-2021
To cite this article: Obielodan, O. O., Onojah, A. O., Onojah, A. A., Alabi, O. S., \& Alimi, E. A. (2021). The teachers' extent of utilizing teaching methods for teaching basic technology. Journal of Research in Instructional, 1(2), 61-70. https://doi.org/10.30862/iri.v1i2.14

*Corresponding author: haymoresonojah@gmail 


\section{INTRODUCTION}

When instructors are able to comprehend theories and successfully employ various instructional techniques, teaching becomes more successful. Because teachers are the implementers, the success or failure of any planned curriculum is highly reliant on them. As a result, if the professors who are intended to instill information in learners are inept, inexperienced, or untrained, the students' performance will suffer. Effective teaching is closely correlated with student performance such as skills and knowledge so that they can function for society (Briggs, 2019). Learners have their own techniques for each activity they do. The technique itself can be obtained and developed by following classroom learning. Effective learning methods by teachers are tools that can be used to improve students' abilities. Teachers must be able to identify and use the right types of teaching methods that can change and empower the behavior of their students.

The learner, on the other hand, must be engaged in order for learning to take place; the student is the one who must make the commitment to learn. As a result, being able to inspire, encourage, retain, and keep students' interest and attention when it comes to learning is critical as a successful teacher. Learning can permanently change student behavior for the good (Okoye, 2010). When a person's behavior is impacted or changed in such a way that the person thinks or acts differently as a result of newly acquired skill, principles, facts, information, or knowledge, it is then when learning is considered to have occurred. Learning entails giving instructions to the student and having him acquire certain skills, information, knowledge, or other established data (Lelasari et al., 2021; Onojah et al., 2019). The technique refers to how the training or teaching is carried out in order to attain the given educational goals.

No society grows as expected without investing in their education system because a territorial army of sheep commanded by a lion could overthrow a militia of lions controlled by a sheep; this depicts the need to value education (Onojah et al., 2020). The concepts and techniques of education employed by instructors to accomplish the intended learning in pupils are referred to as teaching methods (Aco et al., 2021). These approaches are based in part on the subject matter to be taught, in part on a behavioral goal, and in part on the character of the learners' background. In order for a teaching technique to be effective and suitable, it must first be tested and has to be in relation to the characteristics of the learner and the type of learning objectives to be achieved (Ruto et al., 2021). A teaching technique is a tool used by teachers. Teachers in Ilorin East, Kwara state, employ a variety of teaching methods for various purposes, most notably for teaching basic technology in junior secondary schools. Education brings out all of the beauty and perfection that a person is capable of in his or her body and spirit as a result of what he or she has learned (Murphy, 2015). According to Education for the Twenty-First Century, lifelong learning and active involvement in a society of learning are essential to successfully confronting the difficulties offered by a fast-changing world. The Commission highlights four pillars of learning: "learning to live together," "learning to know," "learning to do," and "learning to be." "Learning to live together" (UNESCO, 2005).

It is germane for teachers always to be interested in the link between teaching techniques and student academic achievement, particularly when it comes to implementations in 21st-century education (Briggs, 2019). There appears to be something about teaching that opens the door to learning. Even though a number of teacher-related 
elements impact effective learning, the approaches that a teacher employs continue to play an essential part in student learning as well as their academic progress. Teaching is the act of listening to and responding to learners' needs, experiences, and emotions and intervening so that they learn certain things and progress beyond the present situation (Carless, 2020). Because the difficulties that educators confront in the twenty-first century are so diverse, effective teaching approaches are more important than ever. Furthermore, the effect of any instructional approach is not limited to the contexts in which it is used; nonetheless, the advantages and disadvantages of a particular method in a certain environment should not be neglected, especially in the context of a global health catastrophe such as COVID-19 (Allen et al., 2020). There is no teaching method that is the best, nor is there any technology adopted to facilitate learning that should be regarded as the best. Learning situation or context determines the method and technology that best suits any learning (Onojah et al., 2020).

As a result, secondary education allows for any technique that may aid in student learning while still achieving the specified goals. Despite the numerous teaching techniques proposed in the literature, no single method is widely recognized. The issue remains as to whether these instructional approaches contribute to student performance failure or success, particularly in developing country Nigeria, where the reasons for low performance in secondary schools are not well recognized. As a result of this, the comparative study of some teaching methods and their impact on the academic achievement of students in secondary schools are still worth pursuing.

Gender refers to whether a person is male or female, i.e., whether he or she is a boy or a girl, a man or a woman. Gender is defined by the traits that separate organisms based on their reproductive activities, according to the basic dictionary definition. Sex is also described as a biological feature that distinguishes a person as a male or female. As a result, a person's gender is essentially only a reflection of their preferences for specific qualities that are stereotypically masculine or feminine in nature. In information technology, studies on gender are still prominent because female participation is lower than male (Lau \& Yuen, 2015). The pedagogic knowledge of male teachers is better than female teachers, but the pedagogic knowledge of female teachers is more regular and changes consistently (Abidin et al., 2021). Other research shows that there is no difference in the pedagogic knowledge of male and female teachers (Patra \& Guha, 2017).

Education is a smart investment that is intended to boost individual and societal economic prosperity. It is common knowledge that education is a significant element in social mobility, implying that education has the power to impact a person's future and economic standing in society (Usman, 2015). Regrettably, this vital industry is beset by a slew of issues. Poor academic performance of secondary pupils as a result of the employment of inefficient teaching methods in the classroom is one of the most prominent examples. Any country interested in ensuring a more promising future for its citizens must make significant investments in the education of its citizens (Onojah et al., 2021). All teaching techniques are designed to assist instructors in their efforts to communicate information. However, there is a lack of time spent evaluating certain important variables before deciding on an acceptable approach. Teachers should use suitable teaching approaches that best suit specific objectives, learners, and the degree of desired outcomes to support the process of knowledge transmission. Substantial study on the efficacy of 
teaching techniques, according to (Briggs, 2019), suggests that the quality of teaching methods is frequently mirrored by students' academic performance accomplishments.

In 2017, In Kwara state, a total of 34,832 applicants sat for WAEC as public students, including 18,032 male candidates and 16,800 female candidates. There were 23,361 applicants who had five credits or more in the English language, 26,275 candidates who had five credits or more in Mathematics, and 21,605 candidates who had five credits or more in both English language and Mathematics. The percentage of candidates with five credits above, including English language and Mathematics, is 62.03\%, which involves 60.45\% male pass and $63.71 \%$ female pass candidates. (National Bureau of Statistics, 2019).

According to the Results Statistics 2016-2018 of West African Examinations Council for the entire country (Nigeria), 1.57 million public students sat for WAEC in 2018, compared to 1.56 million in 2017. There were 822,941 male applicants and 748,595 female candidates. Total 849,069 applicants received five or more credits, including English Language1.06 million applicants had five credits or more in Mathematics, whereas 756,726 candidates had five credits or more in English language and Mathematics. The percentage of applicants having five or more credits in Math and English Language is estimated to be 48.15 percent (National Bureau of Statistics, 2019); as a result, the purpose of this study was to find out how much teachers used instructional methods for teaching Basic Technology in Kwara State, Nigeria.

The main purpose of this research was to find out the extent of utilizing teaching methods for teaching Basic Technology. Specifically, the study:

1. This research is to determine the extent of utilizing teaching methods for teaching basic technology.

2. Investigated the influence of gender on teachers' extent of utilizing teaching methods to teach basic technology

The research provided answers to the following two questions:

1. What are the extents of utilizing teaching methods in teaching basic technology?

2. Does gender influences teachers' extent of utilizing teaching methods for teaching basic technology?

\section{METHOD}

This section presents the method and procedures that were used in this study to gather and analyze the data that was collected in this study. It has been presented under the following subheading; design of research, sample and sampling techniques, instrument research validation, data collection procedure, and data analysis techniques.

Jackson (2012) defined research design as a strategy for gathering and analyzing information from a group of people via interviews or the administration of a questionnaire. The descriptive research technique used in this study is a survey-based approach. It was decided to conduct a survey for this study because it allowed the researcher to gather huge quantities of information regarding the degree to which instructors in Kwara state, Nigeria, used teaching techniques for the purpose of teaching fundamental technology.

The term population as used in this research consists of all the entire number, group, and element that interest the researcher. The population of the study was teachers in secondary schools that teach basic technology in Ilorin East Kwara state Nigeria, and in addition, is a teacher for the subject. The target population comprised basic technology 
teachers that were randomly selected in some of the junior secondary schools in Ilorin East Kwara state Nigeria.

The basic technology teachers were selected from each of the schools, bringing the sample to one hundred and thirty (130). The available basic technology teachers who teach basic technology subjects were sampled. That is, the sample population comprised of teachers from six (66) sample schools that were randomly selected.

The research instrument was a researcher-designed questionnaire titled the 'Teachers' Extent of utilizing Teaching Methods for teaching Basic Technology in Ilorin East local government area, Kwara State, Nigeria.' The instrument comprises sections A and B.

Section A of the students' questionnaire requires the respondents' Demographic information, which includes the name of the school and gender been rated as both male and female. Section B in the questionnaire focus on the extent of utilization of basic technology teaching method. Seven different relevant questions were generated for this section. The items in the questionnaire are rated on a modified four points scale of AU (Always use), OU (Often Us), RU (Rarely use), and NU (Never use). The methods used in this research are the question and answer teaching method, discussion teaching method, Role playing teaching method, inquiry and discovery (assignment) teaching method, Field trip teaching method, game and simulation teaching method, and the Project and presentation teaching method.

The relationship between the data and the variable or construct of interest is established via the validity of the data. A research's accuracy in representing a specific variable or construct was determined by estimating the accuracy of the data acquired in the study. Several lecturers from the University of Ilorin's Educational Technology Department vetted the questionnaire used in this study to ensure that it had both face and content validity. The questionnaire was vetted by the researcher's supervisor as well as four other lecturers from the department to ensure that it had both face and content validity. Their thoughts and recommendations were utilized to make changes to the instrument's elements as well as to construct the final document. The researchers went to the specified secondary schools and handed out questionnaires to the instructors in a kind and accessible way, taking into consideration their mood and circumstances. The researcher collected back the copies of the questionnaire after the samples had responded to the items in the questionnaire and collated the data for analysis.

The data obtained from the administered questionnaire was subjected to descriptive and inferential statistics. Percentage and mean were used to answer research questions 1 and 2, while Mann-Whitney was used to test the research hypotheses. Data is coded and analyzed using a statistical package for the social sciences (SPSS) version 25.0 at a 0.05 level of significance.

\section{RESULTS}

In this section, we present the results of the analysis and interpretation of the research results. The demographic distribution of respondents' gender was analyzed using percentages. The research questions were answered with the mean and standard deviation data, while the hypothesis testing was calculated using the t-test. This research provides answers only to research questions without appropriate hypotheses. However, all other research questions with the appropriate hypothesis were hypothesized and tested through the corresponding hypothesis. 
In addition, 130 copies of the research instrument were administered, but 122 copies were properly filled and returned and were thus used for the analysis in this study at a return rate of $93.85 \%$ response rate. The results are presented as follow:

The distribution of students on gender was analyzed. The students' gender was described using a percentage as shown in Table 1.

Table 1. Demographic information of participants based on genders

\begin{tabular}{ccc}
\hline Gender & Frequency & Cumulative (\%) \\
\hline Male & $51(41.8 \%)$ & $41.8 \%$ \\
\hline Female & $71(58.2 \%)$ & $100.0 \%$ \\
\hline Total & 122 & \\
\hline
\end{tabular}

Table 1 shows the demographic information of the respondents' gender. It indicated that out of $122(100 \%)$ respondents sampled for this study, $51(41.8 \%)$ of the respondents were male, while 71 (58.2\%) of the respondents were females.

In other to justify the extent to which basic technology teachers apply different teaching methods is reported and analyzed with frequency count and percentage. The result is shown in table 2 .

Table 2. The extent of utilizing teaching methods for basic technology

\begin{tabular}{|c|c|c|c|c|c|}
\hline $\mathbf{S} / \mathbf{N}$ & Basic Technology Teaching Method & $\begin{array}{l}\text { Always } \\
\text { Use }\end{array}$ & $\begin{array}{c}\text { Often } \\
\text { Use }\end{array}$ & $\begin{array}{l}\text { Rarely } \\
\text { Use }\end{array}$ & $\begin{array}{l}\text { Never } \\
\text { Use }\end{array}$ \\
\hline 1. & Question and answer teaching method & $\begin{array}{l}92 \\
(75.4 \%)\end{array}$ & $\begin{array}{l}24 \\
(19.7 \%)\end{array}$ & $\begin{array}{l}6 \\
(4.9 \%)\end{array}$ & -- \\
\hline 2. & Discussion teaching method & $\begin{array}{l}77 \\
(63.1 \%) \\
\end{array}$ & $\begin{array}{l}35 \\
(28.7 \%) \\
\end{array}$ & $\begin{array}{l}7 \\
(5.7 \%) \\
\end{array}$ & $\begin{array}{l}3 \\
(2.5 \%) \\
\end{array}$ \\
\hline 3. & Role playing teaching method & $\begin{array}{l}38 \\
(31.1 \%)\end{array}$ & $\begin{array}{l}44 \\
(36.1 \%)\end{array}$ & $\begin{array}{l}24 \\
(19.7 \%)\end{array}$ & $\begin{array}{ll}16 \\
(13.1 \%) \\
\end{array}$ \\
\hline 4. & $\begin{array}{l}\text { Inquiry and discovery (assignment) } \\
\text { teaching method }\end{array}$ & $\begin{array}{l}61 \\
(50.0 \%)\end{array}$ & $\begin{array}{l}36 \\
(29.5 \%)\end{array}$ & $\begin{array}{l}20 \\
(16.4 \%)\end{array}$ & $\begin{array}{l}5 \\
(4.1 \%)\end{array}$ \\
\hline 5. & Field trip teaching method & $\begin{array}{l}40 \\
(32.8 \%)\end{array}$ & $\begin{array}{l}28 \\
(23.0 \%) \\
\end{array}$ & $\begin{array}{l}40 \\
(32.8 \%)\end{array}$ & $\begin{array}{l}14 \\
(11.5 \%) \\
\end{array}$ \\
\hline 6. & Game and simulation teaching method & $\begin{array}{l}26 \\
(21.3 \%)\end{array}$ & $\begin{array}{l}41 \\
(33.6 \%)\end{array}$ & $\begin{array}{l}36 \\
(29.5 \%)\end{array}$ & $\begin{array}{ll}19 \\
(15.6 \%) \\
\end{array}$ \\
\hline 7. & $\begin{array}{l}\text { Project and presentation teaching } \\
\text { method }\end{array}$ & $\begin{array}{l}48 \\
(39.3 \%)\end{array}$ & $\begin{array}{l}23 \\
(18.9 \%)\end{array}$ & $\begin{array}{l}20 \\
(16.4 \%)\end{array}$ & $(4.1 \%)$ \\
\hline
\end{tabular}

The extent to which basic technology teachers utilize teaching methods in teaching basic technology was reported in table 2 . It indicated that $75.4 \%$ of the entire respondents always employ the question and answer teaching method while $19.7 \%$ moderately employ the method. Others are shown in table 2. This established that question and answered discussion, inquiry, and discovery, field trip, and project and presentation teaching methods are always employed by basic technology teachers in teaching while role-playing, game, and simulation teaching method are moderately utilized for teaching. 
The significant difference between male and female teachers' extent of utilizing teaching methods to teach basic technology in schools was examined, and Mann-Whitney was used to analyze if the differences were significant.

Table 3. Mann-Whitney on Significant Difference Between Male and Female Teachers' Extent

\begin{tabular}{lccccccc}
\hline Gender & $\mathbf{N}$ & $\begin{array}{c}\text { Mean } \\
\text { Rank }\end{array}$ & $\begin{array}{c}\text { Sum of } \\
\text { Ranks }\end{array}$ & $\mathbf{U}$ & $\mathbf{W}$ & $\mathbf{Z}$ & $\begin{array}{c}\text { Sig. (2- } \\
\text { tailed) }\end{array}$ \\
\hline Male & 51 & 73.42 & 3746.00 & & & & \\
\hline & & & 1362.000 & 3967.000 & -2.612 & 0.025 \\
\hline Female & 71 & 53.98 & 3903.00 & & & & \\
\hline Total & 122 & & & & & & \\
\hline
\end{tabular}

Table 3 shows that there is a statistically significant difference in the amount to which male and female basic technology instructors employ instructional techniques for teaching $[\mathrm{U}=1362.000, \mathrm{p} .05]$. Taking into account mean rankings, it was discovered that the amount to which male basic technology teachers utilize teaching techniques for teaching basic technology is much more than the extent to which female basic technology teachers use teaching methods for teaching basic technology.

\section{DISCUSSION}

Research question one sought to find out the extent of the utilization of each basic technology teaching method; the result obtained showed that question and answer, discussion and inquiry, and discovery are the most frequently used teaching method by the majority of the teachers teaching basic technology. All these methods mention ed earlier are all types of student-centered teaching method, which is considered effective types of teaching approach. They are effective in the sense that they allow learners to take responsibility for their own learning, which means learners determine how a topic will be treated, which helps improve their thinking, accommodation, and assimilation on the concept being taught.

While teaching methods such as role-play, game and simulation, project and presentation, and field trips are occasionally (rarely) been used for teaching basic technology, as indicated by the finding of the research. These other methods are rarely being used because they all require additional skills in other to use them, most of which are missing in teachers. The field trip teaching method is mostly avoided by teachers because it is expensive, and most schools only have a limited amount of resources. This supports the research of Kitti (2014), which reveals that the question and answer method is the most widely used method in teaching teachers in Tanzania (81.4\%). The next method is group discussion (78.6\%), followed by presentations and brainstorming (77.1\% and $71.1 \%)$. Three other methods that received low scores, namely demonstration (58.6\%), seminar (41.5\%), and lecture method (38.5\%), were in the last position.

This study shows a strong indication that question and answer, discussion, inquiry and discovery, field trip, and project and presentation teaching methods are always employed by basic technology teachers in teaching while role-playing, game and simulation 
teaching methods are moderately utilized for teaching. Which means that majority of basic technology teacher prefer to used simple and also traditional methods of teaching.

The findings also established that there was a significant difference between male and female teachers' extent of utilizing teaching methods to teach basic technology in favor of the male basic technology teachers. This support the findings of (Dorgu, 2015) who stated that the demonstration which involves showing, doing or telling the students the point of emphasis is mostly used by male teachers as a technique within a method of teaching and at times as a method of teaching itself. However, in the use of learning resources based on technology, there is no difference between male and female (Ameen et al., 2019). Female teachers have a greater impact than male teachers in learning (Olivia et al., 2018). In this study, the highest response was given by male teachers.

\section{CONCLUSION}

This research examined the extent at which teachers utilize teaching methods for teaching basic technology in Kwara state, Nigeria. The results obtained from the data gathered and analyzed in this study helps established the fact that question and answer, discussion, inquiry and discovery, field trip and project and presentation teaching method are the most utilized method by basic technology teacher, while role playing, game and simulation teaching method are moderately utilized for teaching. Educating the brain and education the mind without educating the heart is an incomplete task because probity and knowledge make a successful learner. Male basic technology teachers' extent of use of teaching methods for teaching basic technology are significantly greater than those of female basic technology teachers.

Based on the findings and conclusions of this study, the following recommendations were made.

1. Schools, educational institutions, government and non-governmental organizations should organize conferences, seminar, training and workshops for basic technology teachers on the use of effective teaching methods that will facilitate better students' academic performance in the subject. This will also assist teachers in appreciating and learning the best teaching practices, especially new teaching methods.

2. Tertiary institutions such universities, polytechnics, college of educations and institute of educations should train pre-service teachers on use of effective teaching methods for teaching students when still in training. They should also provide such training for inservice teachers.

3. Educational authorities, schools should stop employing unqualified teachers henceforth. This help in screening out people without educational background in the subject are, thereby preventing possible future students' failure as a result of used of ineffective teaching method by the unqualified teacher.

\section{REFERENCES}

Abidin, Z., Hindiriana, A. F., Lismaya, L., \& Junaedi, E. (2021). Profile of changes in pedagogical content knowledge of biology teacher candidates based on gender. Proceedings of the 1st Universitas Kuningan International Conference on Social Science, Environment and Technology, UNiSET 2020, 12 December 2020, Kuningan, West Java, 
Indonesia, 1-6. https://doi.org/10.4108/eai.12-12-2020.2305124

Aco, S. N., Rahman, S. R., \& Firman, F. (2021). Using inquiry-based learning to strengthen student learning outcomes. Journal of Research in Instructional, 1(1), 1-12. https://doi.org/doi.org/10.30862/jri.v1i1.2

Allen, J., Rowan, L., \& Singh, P. (2020). Teaching and teacher education in the time of COVID19. Asia-Pacific Journal of Teacher Education, 48(3), 233-236. https://doi.org/10.1080/1359866X.2020.1752051

Ameen, K. S., Adeniji, S. M., \& Abdullahi, K. (2019). Teachers' and students' level of utilization of ICT tools for teaching and learning mathematics in Ilorin, Nigeria. African Journal of Educational Studies in Mathematics and Sciences, 15(1), 51-59. https://doi.org/10.4314/ajesms.v15i1.5

Briggs, B. (2019). Teaching methods as correlate of student performance in business studies in selected public secondary schools in Port Harcourt. International Journal of Innovative Social |\& Science Education Research, 7(2), 1-12.

Carless, D. (2020). Longitudinal perspectives on students' experiences of feedback: a need for teacher-student partnerships. Higher Education Research \& Development, 39(3), 425-438. https://doi.org/10.1080/07294360.2019.1684455

Dorgu, T. E. (2015). Different teaching methods: A Panacea for effective curriculum implementation in the classroom. International Journal of Secondary Education, 3(6), 77-87. https://doi.org/10.11648/j.ijsedu.s.2015030601.13

Jackson, C. K. (2012). Non-cognitive ability, test scores, and teacher quality: evidence from 9th grade teachers in North Carolina (No. 18624; NBER Working Paper Series). https://doi.org/10.3386/w18624

Kitti, M. R. (2014). Effect of teaching methods on students' performance in Tanzanian education institutions: A case of public secondary schools in Nyamagana District Mwanza [The Open University of Tanzania]. https://muhaz.org/mwanahamisi-rkitti.html

Lau, W. W. F., \& Yuen, A. H. K. (2015). Factorial invariance across gender of a perceived ICT literacy scale. Learning and Individual Differences, 41, 79-85. https://doi.org/10.1016/j.lindif.2015.06.001

Lelasari, T., Yohanita, A. M., \& Damopolii, I. (2021). Effect of inquiry science learning on students' metacognitive skill. Journal of Research in Instructional, 1(1), 53-60. https://doi.org/10.30862/jri.v1i1.12

Murphy, M. (2015). Plato's philosophy of education and the common core debate. Association for the Development of Philosophy Teaching (ADOPT) Spring Conference, 112.

National Bureau of Statistics. (2019). WAEC Results 2016 - 2018. Abuja, Nigeria: Proshare.

Okoye, K. R. E. (2010). Enhancing quality in educational practice and instructional delivery by teachers of technology and vocational education in Nigeria. African Research Review, 4(2), 355-369.

Olivia, M., Jalmo, T., \& Setyorini, M. (2018). PCK in science education: Perception of science teacher on PCK instruments. IOSR Journal of Research \& Method in Education, 8(4), 3744. https://doi.org/10.9790/7388-0804043744

Onojah, A. O., Onojah, A. A., \& Odewumi, M. O. (2021). Undergraduate students' intention to utilize flipped classroom strategy for learning. Pakistan Journal of Educational 
$\begin{array}{llll}\text { Research } & \text { and } & \text { Evaluation, }\end{array}$ http://111.68.103.26/journals/index.php/PJERE/article/view/4468

Onojah, A. O., Olumorin, C. O., Adegbija, M. V., \& Babalola, T. O. (2019). Perception of undergraduate students on the utilization of flipped classroom for learning in SouthWest Nigeria. Malaysian Journal of Distance Education, 21(1), 95-112. https://doi.org/10.21315/mjde2019.21.1.6

Onojah, A. O., Onojah, A. A., Olumorin, C. O., \& Abimbola, I. O. (2020). Study technology: The Suitable tenacity to learning snags. JPI (Jurnal Pendidikan Indonesia), 9(3), 497-507. https://doi.org/10.23887/jpi-undiksha.v9i3.25191

Patra, A., \& Guha, A. (2017). Comparative study on geography teachers' Pedagogical Content Knowledge (PCK) and self-efficacy in West Bengal. Journal of Research in Humanities and Social Science Volume, 5(3), 68-71.

Ruto, R., Mema, A., Nduru, M. P., \& Ota, M. K. (2021). Contextual teaching and learning approach in social science: its role to encourage pupils' cognitive learning achievement. Journal of Research in Instructional, 1(1), 43-52. https://doi.org/10.30862/jri.v1i1.11

UNESCO. (2005). Links between the Global Initiatives in Education. Paris: United Nations Educational, Scientific and Cultural Organization.

Usman, Y. D. (2015). The Impact of instructional supervision on academic performance of secondary school students in Nasarawa State, Nigeria. Journal of Education and Practice, 6(10), 160-167. 